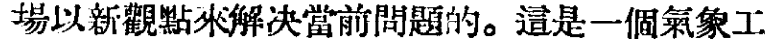
作者重要的集會, 它砂究了當前氣像工作者共同 努力的方向開題, 是中國氣像事業發展上的一個 重荘的里程做。因此, 大會收獲是極大的。首先, 大 家在思想上向前邁進了一步, 每位代表都了解了 客觀情况和贵際需要, 因而也明確了氣像工作的 方針和任務,並在對於如何配合, 如们進行的問題 上,確立了一些基本原則。其次,通過了會章,成立 了組織，使我們有一倜具體的機構隶掌握這些問
題。第三，經過了專題報告，使我們對國內過去以 及當前的情况和登展, 對近代篓像學的潑展, 有了 基本上的了解。最後, 經過部父文報告, 了解了虽前 研究的一般情况, 在研究的方法上, 給予了我們一 定的綮示。大會的缺點是淮借不的，㭙間食促，專 題和諭交討論還不够深人。大會的優點琴民主和 認葚。這個傮點希望帶到每倜分會。大會就在熟烈 的掌罄中勝利地閉幕了!

（噼秀灌）

\title{
西北幾省的地磁測 量
}

\section{前 畨}

地磁場的强弱和方向各地不闰, 泣且隨時在 變, 我們婆想了解地面上磁場的分佈情形和他自 過去到現在的變化趝勢, 每隔相虽㭙間必須到各 地去测量一次。测量的地點愈密，(通常各點相百. 距離自幾十公里至百多公里) 複测的洔距永短, （五年至十年）對地磁場的分作與變化就知道得恿 清楚。

硒北各省地磁, 國人始終浔有去作過有計劃 的测量, 40年湔外人踓曾测過, 逾洔既久, 测等又 疏，長時間內地磁變化很大, 彼时测得數倠决不能 適用於今日。我們第明瞭現在國內地磁場的分作

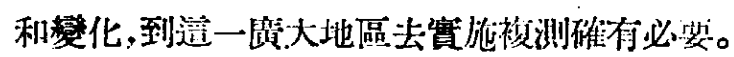

1950年秋, 中央組織西北远族訪問團,科學院 以時機難得, 决定派一地磁觀测除隨橉去西北工.

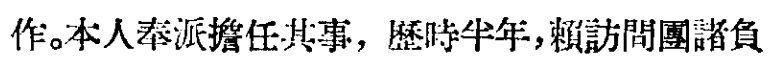
責闹志與各級地方政府之協助, 得以順利遵成任

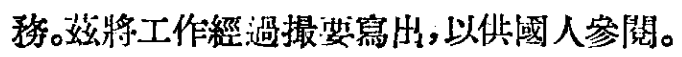

\section{測量區域}

8 月初由挐去京, 向訪問團報到, 參加政治學 晳。8月底隨團襍京西上, 先抵西安, 循陝甘公路去 闌州。即以米州第據點, 南去拉布楞和勨夏; 西去 青海等地訪間。各兄弟民族哀心感謝毛主席和中

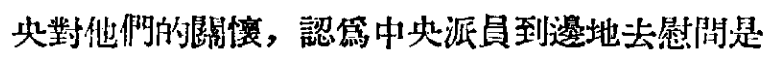

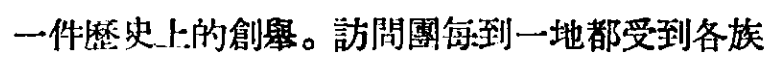
各界人上等烈歡迎。

自青海返蘭時已是 11 月初, 天氣漸冷, 訪問團
任称完成即首途返京。地磁除因工作未完, 在蘭州 踓團,繼續進行测量。

隨圍工作期間, 凡訪問團在一地停留兩天以 上,我們即進行觀測工作，其間計测得北京、西安、 闌州、臨夏、西寗等五點。在訪問團去甘南拉布楞 一帶訪問時,因罍地情形特殊, 不便作科學調查,

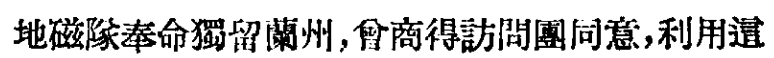
一段時期單獨去河西走廊工作，在短短牛個月內 测得酒泉、張掖、正减、永登等四點。

地磁隊除開訪問團後即北去察夏, 化一個月

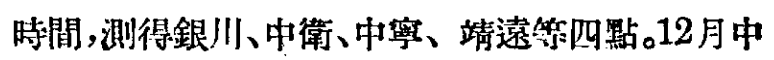
旬返抵蘭州, 而後取道䧗洮、隴西至天水, 再循隴 海路沿線测至鄭州, 計测得臨洮、㜔西、天水、責

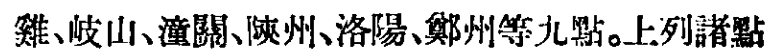
中, 蘭州會複测三次, 西安複测一次。

\section{交通與氣候}

各大城市都通汽車,幾條公路幹線路面平坦, 保食得很好。較小城市也有馬車可達。测量工作的 進度受交通情形的限制很大，坐馬車每點本均的 需八天，公路沿線每故約需五天，天水以東因第 有火車, 僅需三、四天即可完成一點。(圖)一示西北 使用的交通工具一羊皮筏, 上面载的都是测量 儀器)

西北係大陵性氣候, 冬天酷冷, 很不適宜進行

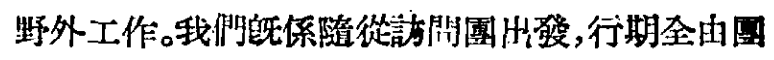
部决定, 明知那透冬季不適它做野外工作, 篇了時 機難得,也不願錯過這個機會。

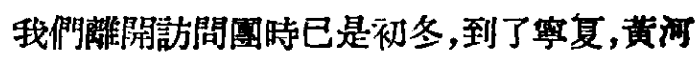




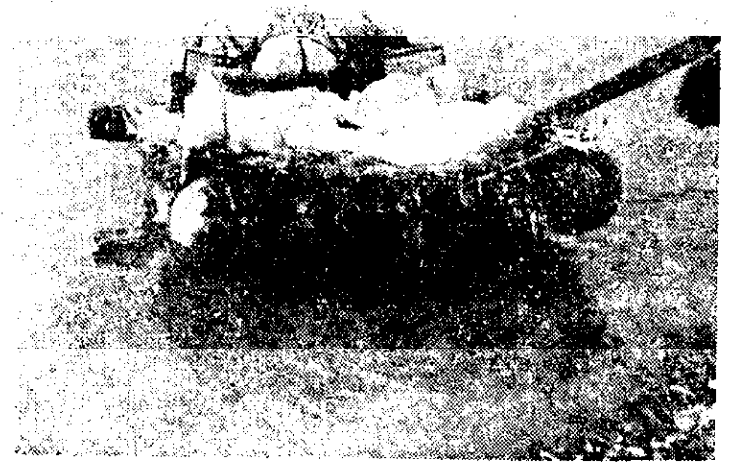

㘣一

整未封凍，土地却已凍掔。第支架儀器須在地下安

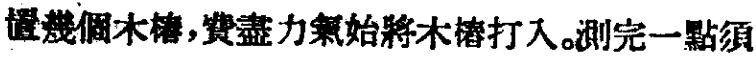

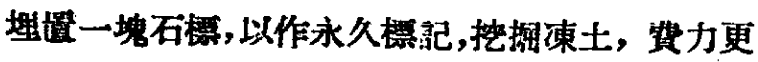
大，常膤掘一個一尺方二尺深的土坑，燃木柴、澆 開水，歴三、四小時始克完成。

所测二十幾點，有牛数以上保在氣温骦氏表 零度以下進行的，鼠冾到過零下 15 度。白天有太 星，不然風份不兒冾，比较狼苦的是夜間的测星工

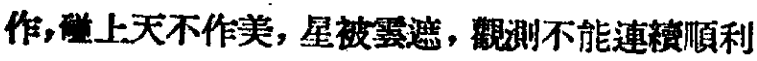
進行,常須工作至深夜。

\section{工作粞事}

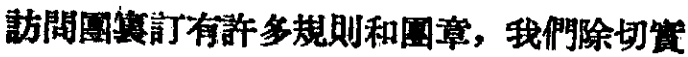

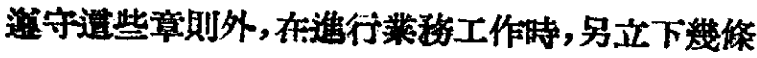
守則,認员宾行：

1.儀器的愛護 地磁测量全靠儀器, 儀器有

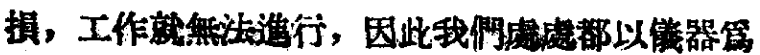

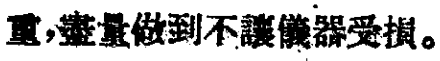

2.記管的可举性 测量目的在收集弲錄，記

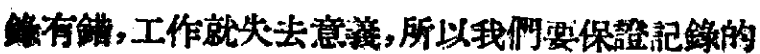

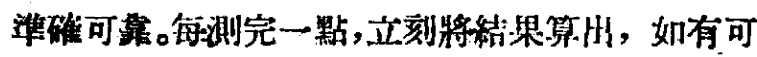
疑，第二天必必須復作觀测。

3. 時間的掌握 野外工作時間特别䆩贵, 必 須好好掌握，如計劃不週或動作䌊慢，有時會因一 件小事新擱烧天時間。夜間㴊星受天时限制。更不 旨輕易故過一個晴天。(圖二示测焦用的經綿侍)

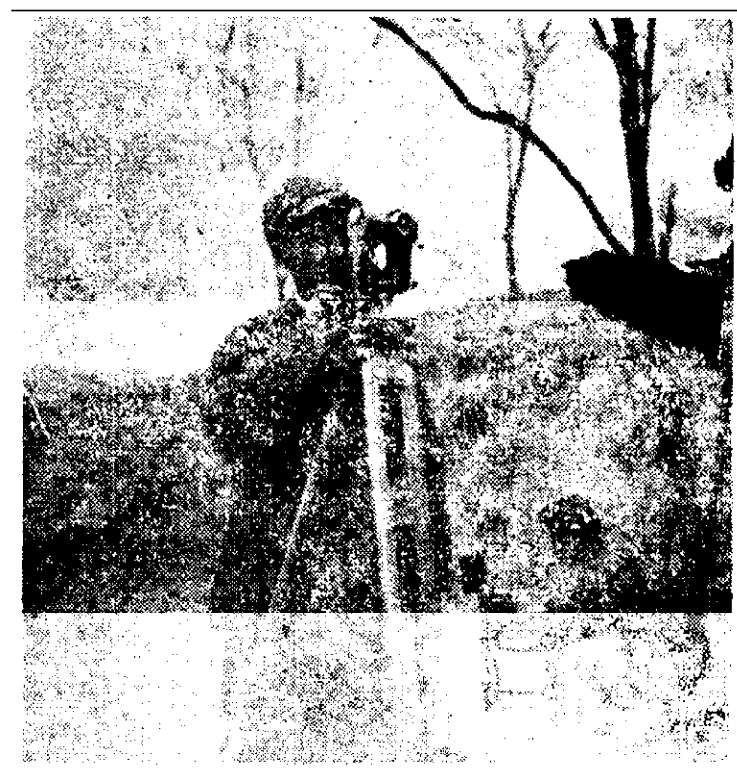

圖三

\section{收 礶}

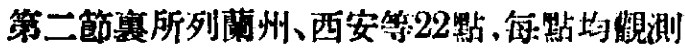
兩天一晚，除觀剆各點地磁場的偏角，倾佮和水平 强度外，並测定各測點的經度和緯度。全部記錄已 整理聡事,隨媵另文發表。

\section{忘的協助}

我們篇求得工作上的方便和石標的永久保持

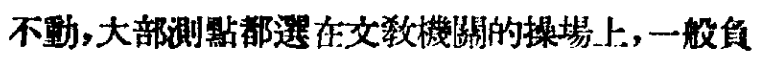
责同志對科舉工作都十分重赔，我們常可得到希 望以外的協助, 使工作得以順利進行, 员使我們感 敏難忘。

（中國科㩆院地球物理研究所 胡岳仁）

\section{廣西大學經濟植物研究所工作摡要}

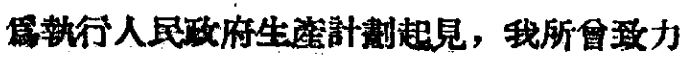

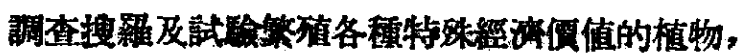
亚力求達到大量推廣及利用，以㭚進我國資源，落 将過去主䋢工作分錄於下：
一、橡翼植物的發現及策殖：

(一)在梧州附近弡現橡膠代替植物奶汒筮 (Chonemorpha spp.):經插攸繁殖成活㮦85\%,已

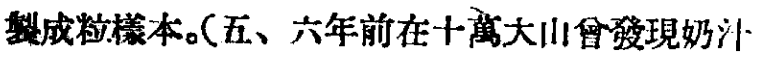

